transuranic elements in the "island of stability" (atomic numbers 114-120), studies of black holes and quarks. $\mathrm{Mr}$ Leonid Brezhnev, at the twenty-sixth Party congress, had emphasized the need for "fruitful cooperation of all states" on these problems, yet Sakharov has been unable to meet or correspond with his colleagues abroad since 22 January 1980.

\section{Vera Rich}

\section{UK industrial research All change}

Britain's Department of Industry has reorganized the way in which it supports industrial research, seemingly to counter criticism that it has been poor at defining priorities and has relied too heavily on reacting to research proposals from industry. The nine research and development requirements boards, each aimed at a particular sector of industry, have been replaced by five boards, each dealing with a particular technology.

The five new boards are to cover the same spread of research as the old ones, the idea being that by increasing the spread of each board's responsibilities the government's definition of long-term objectives and priorities will be made easier. Hence for example, the new Mechanical and Electrical Engineering board will take over the work of the old Ship and Marine, Mechanical Engineering and Machine Tools and Electrical Technology boards. The old Chief Scientist's board, which considered topics not covered by the other boards, is to be incorporated into the new Textile and Other Manufactures board.

The other new boards are Electronics and Avionics which replaces Computer Systems and Electronics, Materials and Chemicals which replaces Chemicals and Minerals and Engineering Materials, and Metrology and Standards which remains the same under the chairmanship of $\mathrm{Dr}$ Duncan Davies, now called Chief Engineer and Scientist in the department.

The functions of the new boards will remain largely unchanged. Industry and universities will be able to apply to them for government support for industrial research and they will continue to place contracts for research of their own choosing within industry and the department's own research establishments. The arrangement whereby levies are charged on the profits accruing from research funded by more than 50 per cent by the department will remain. And each board will have an executive committee to approve projects. It is hoped that the reorganization will encourage the boards to place more contracts in priority areas of research. However, the fact that there are no plans to appoint subcommittees has led to some fears that the boards' remits could be too wide to be effective.

The department's budget for industrial research is to remain roughly constant. This year it is $£ 600$ million, $£ 35$ million of which will be spent in industry and $£ 25$ million in the department's research establishments. A small saving in funds will be made from the reduction in staff expected to follow the reorganization.

Judy Redfearn

\section{Bioengineering hazards Europe doubts}

Brussels

An inconclusive meeting on the safety aspects of research on recombinant DNA was held here last week by the European Community's Economic and Social Committee (ESC). At this stage, it is hard to tell whether the meeting will influence the development of Community legislation on the subject - and, if so, in what direction that influence will be directed.

The discussions ranged from the longterm ethical problems posed by the possibility of tampering with human genes to the risks of accidentally releasing a new and dangerous strain of microorganism. The impetus for the meeting was the European Commission's draft recommendation on the registration of DNA research - ESC is required to give an opinion before the Council of Ministers make a decision.

Most participants seemed to agree that industry was already being over-cautious. By trying to avoid the mistakes of the nuclear industry, the safety measures recommended in the early 1970 s for DNA research now seem to reflect exaggerated fears.

One pointer in this direction was the conclusion by the European Science Foundation's Liaison Committee on Recombinant DNA in January that recombinant DNA research as such entails no significant novel biohazards. It was also stressed that recombinant DNA techniques can be safer than conventional methods for studying pathogens and toxins. Safety guidelines for handling pathogenic viruses, it was argued, were far more necessary, and the World Heath Organization's guidelines are late in arriving. These are due to be published within the next few months.

It was over the social risks that most of the participants were divided. Representatives of trades unions pointed out that there was a danger that decision-making would be restricted to industry. British speakers pointed out that the British Genetic Manipulation Advisory Group has retained control, but French participants conceded that this was not the case in France and elsewhere. Several participants were convinced that the concentration of knowledge in the hands of industry will iead to commercial (or even military) applications not necessarily beneficial. Calls for less secrecy were, however, answered by reference to the fact that all patents are by definition publicly available.

But does the public have sufficient say over the uses to which the recombinant DNA techniques will be put? This issue overlapped with that of the role of the media in informing the public. By attempting to bridge the gap between the scientist and the layman, was there a danger that the press was exaggerating the dangers or speed of developments in this field?

Although many of the speakers argued that the DNA guidelines were safety regulations looking for a hazard, some members of ESC confirmed afterwards that they were in favour of legally enforced safety regulations, even if they needed to be frequently revised to take into account changes in risk assessment. It was suggested that the Community was merely going through the same process that had taken place in the United States a few years ago, but a little later because of the several countries involved.

Jasper Becker

\section{US defence budget}

\section{Laser destruction}

\section{Washington}

The US Senate last week proposed adding an extra $\$ 50$ million to the budget of the Department of Defense to speed up the research and development of a space-based laser system designed to shoot down incoming enemy missiles. At the same time, a Senate appropriations committee has not passed on Mr Reagan's request for $\$ 20$ million to be added to the Pentagon's construction funds for the current year to begin work on the production of binary chemicals weapons at the Pine Bluff arsenal in Arkansas, although this decision could be overturned in negotiations with the House of Representatives, which has already given its approval for the money.

The decision to add additional funds for the laser system is the result of growing pressure from the US military to respond to reports that the Soviet Union is already testing ways of using lasers to destroy missiles - and in the face of continuing scepticism from several quarters that space-based lasers can in fact be produced with the required degree of reliability and accuracy.

The proposed $\$ 50$ million, which will include a detailed systems definition of a space-based laser weapons system, is a compromise between the $\$ 250$ million being requested by some advocates of the system, and fiscal conservatives concerned about an unnecessarily large expansion of the arms budget, which the Senate approved at a record figure of $\$ 136,500$ million for 1982 .

Asked for comments on the original $\$ 250$ million proposal, Dr John Foster of the Department of Defense's Defense Science Board said it was too soon to accelerate space-based laser development towards integrated space demonstration for any mission, and that "a push toward integrated on-orbit demonstrations would seriously endanger necessary [research and 